ISSN 1991- 8690

website :http://jsci.utq.edu.iq
الترقيم الدولي 8690 - 1991

Email:utjsci@utq.edu.iq

\title{
Electrochemical, thermodynamic and quantum chemical studies of thoron compound as new corrosion inhibitor for $\mathrm{C}$-steel in Acidic Media
}

\author{
Munther Abdul-Jaleel Mohammed-Ali* \\ Alaa Ali Husain** \\ Ekhlas Qanber Jasim* \\ * Pharmaceutical Chemistry Department- College of Pharmacy- Basrah University-Basrah, Iraq \\ ** Chemistry Department - College of Education for Pure Sciences - Basrah University- Basrah, Iraq
}

*E-mail: muntheralamery@yahoo.com

\begin{abstract}
$\underline{\text { Abstract }}$
The corrosion rates in the presence of thoron as a steel corrosion inhibitor in $1 \mathrm{M} \mathrm{HCl}$ and $1 \mathrm{M} \mathrm{H}_{2} \mathrm{SO}_{4}$, were measured by the weight loss method, potentiodynamic polarization measurements and quantum chemical calculations. The weight loss method was studied in different times (1-4 hr) and in the range of temperatures from 298 to $318 \mathrm{~K}$. Results obtained revealed that thoron performed excellently as a corrosion inhibitor for C-steel in these acids media and its efficiency attains to $91.99 \%$ at $1 \times 10^{-3} \mathrm{M}$ at $298 \mathrm{~K}$, and by potentiodynamic polarization measurements its efficiency attains to $93.74 \%$ in the same conditions. The Langmuir adsorption isotherm was tested for their fit to the experimental data. The apparent activation energies, enthalpies and entropies of the dissolution process and the free energies and equilibrium constants for the adsorption process were determined and discussed. All the computed quantum chemical parameters are found to correlate well with experimental inhibition efficiencies of inhibitor.
\end{abstract}

Keyword: corrosion, azo dye, thermodynamic, quantum chemistry.

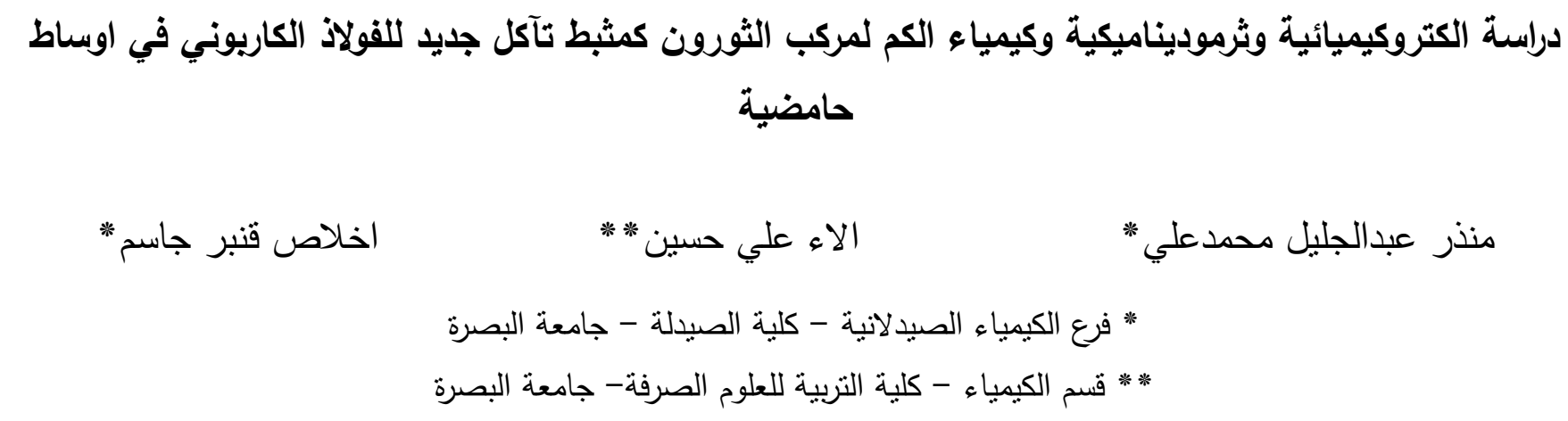

الخلاصة

تم قياس سرعة التآكل بوجود مركب الثورون كثنبط للتاكل للفولاذ الكاربوني في وسطين 1مولاري من كل من حامض الهيدروكلوريك وحامض الكبريتيك باستخدام طريقة الفقدان بالوزن وقياسات جهـ الاستقطاب وحسابات كيمياء الكم. درست طريقة الفقدان بالوزن في ازمان (1- 
4 ساعات) ضمن مدى حراري 298- 318 كلفن. اشارت النتائج ان لمركب الثنورن فعالية تثبيط ممتازة للفولاذ الكاربوني في هذه الوساط

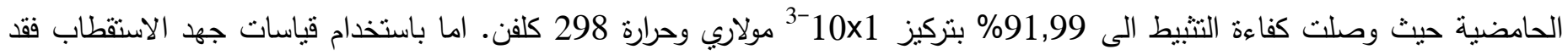
وصلت الكفاءة الى 93,74\%. كما لوحظ ايضا، ان امتزاز الجزيئات على سطح المعدن يخضع لمعادلة امتزاز لانكماير • تم تعيين قيم الثوابت الثرموديناميكية، طاقة التتشيط وحرارة التفاعل والعثوائية لعملية ذوبان السبيكة وتم كذلك تعيين الطاقة الحرة وثوابت الاتزان لعملية الامتزاز ، وتم مناقشة هذه النتائج. وجد هناك تتاسق كبير بين القيم العملية لكفاءة التنبيط والقيم المحسوبة من كيمياء الكم.

\section{Introduction}

Mild steel in acid solution is widely used in various industrial processes and corrosion of mild steel known to occur in this environment [1,2]. One of the effective methods to prevent corrosion is the use of organic inhibitors [3]. Organic inhibitors were adsorbed on a metallic surface. Water molecules at metallic surface are replaced by organic inhibitor molecules. In case of chemisorption, the formation of a bond between the metal and organic inhibitor impedes the anodic and cathodic processes, thereby protecting the metal surface [3]. Furthermore, inhibitor adsorption is influenced by factors such as the nature and surface charges on the metal, type of aggressive media, structure of inhibitor, and the nature of its interaction with the metal surface. The effective organic inhibitors contain nitrogen, sulfur and oxygen atoms. Moreover, sulfur containing compounds are preferred for $\mathrm{H}_{2} \mathrm{SO}_{4}$ while those containing nitrogen act more effectively in $\mathrm{HCl}$ [4].

Azo compounds have attracted considerable attention due to their impressive and useful chemical and physical properties [5,6]. Apart from their purely chemical interest, azo ligands have also received special attention because of their mixed soft-hard donor characters $(\mathrm{O}, \mathrm{N}$ and $\mathrm{S}$ donor sites), versatile coordination behavior [7,8], pharmacological properties $[9,10]$ and optical and thermal properties [11].

The aim of the present work is to study the inhibitive action of azo dye compound (thoron) toward the corrosion inhibitor of carbon-steel in $1 \mathrm{M} \mathrm{HCl}$ and $1 \mathrm{M} \mathrm{H}_{2} \mathrm{SO}_{4}$ solutions using weight loss and galvanostatic polarization techniques. The effect of temperature on the dissolution of carbonsteel in free and acidic solutions was also investigated, and some thermodynamic parameters for activation process were computed.

\section{Experimental part}

\subsection{Materials}

Hydrochloric acid, sulfuric acid and acetone were obtained from Aldrich Chemicals. The mono azo dye compound (thoron, o-arsono-phenylazo-2naphthol-3,6-disulfonic acid sodium salt) used as inhibitor was obtained from Merck with the purity better than $98.5 \%$ and has the following structure:-

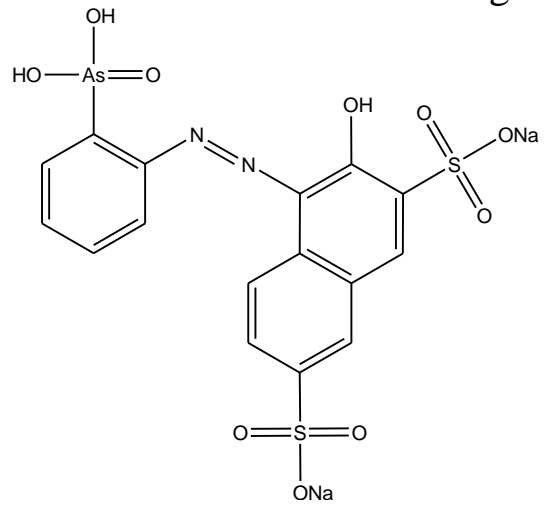

Thoron structure

\subsection{Solutions preparation}

The aggressive solutions $1 \mathrm{M} \mathrm{HCl}$ and $1 \mathrm{M}$ $\mathrm{H}_{2} \mathrm{SO}_{4}$, were prepared by dilution of analytical grade $37 \% \mathrm{HCl}$ and $98 \% \mathrm{H}_{2} \mathrm{SO}_{4}$ with distilled water, respectively. The tested inhibitor (thoron) was prepared in different concentration $1 \times 10^{-5}$, $1 \times 10^{-4}$ and $1 \times 10^{-3}$ in the previous acidic solutions.

\subsection{Weight loss method}

Inhibitor efficiency was determined at 298, 308 and $318 \mathrm{k}$ for $1,2,3$ and $4 \mathrm{~h}$ by immersing vertically the steel coupon of dimensions $3.5 \mathrm{~cm}$ $2.5 \mathrm{~cm} 0.4 \mathrm{~cm}$ into acid solutions $\left(100 \mathrm{~cm}^{3}\right)$ containing various concentrations of inhibitor. 
After the elapsed time, the coupons were cleaned through a procedure that consisted of wiping the coupons with a paper tissue, washing with distilled water, acetone followed by oven drying at $110^{\circ} \mathrm{C}$.

\subsection{Electrochemical measurements}

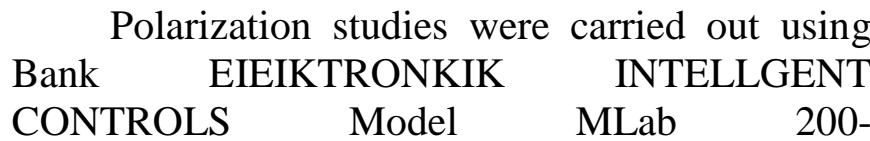
ChemistryDepartment- Education College of pure science - Basrah University. For potentiodynamic polarization studies, mild steel coupons with an exposed area of $2.0 \mathrm{~cm}^{2}$ were used, and experiments were carried out in $100 \mathrm{~cm}^{3}$ of solution containing different concentrations of inhibitor at $25{ }^{\circ} \mathrm{C}$ with the exposure time of $30 \mathrm{~min}$ (or until a steady-state open circuit potential was obtained). Tafel polarization obtained by changing the electrode potential automatically from $(+250$ $\mathrm{mV}$ to $-250 \mathrm{mV}$ ) at open circuit potential with a scan rate $0.5 \mathrm{mV} \mathrm{S}^{-1}$ to study the effect of inhibitor on mild steel corrosion. The linear Tafel segment of cathodic and anodic curves were extrapolated to corrosion potential to obtain the corrosion current densities $\left(I_{\text {corr }}\right)$.

\subsection{Computation of Quantum Chemical} Parameters

Quantum chemistry calculations were carried out by semi-empirical PM3 method from the program package Hyperchem version 7.52, 2002. A full optimization of all geometrical variables without any symmetry constraint was performed at the Restricted-Hartree-Fock (RHF) level. Molecular structures were optimized to the gradient $<0.01$ in the vacuum phase.

\section{Result and discussion}

\subsection{Gravimetric measurements}

\subsubsection{Inhibition efficiency at different times}

Inhibition efficiency $I E \%$, surface coverage $(\theta)$ and corrosion rate $R_{\text {corr }}$. were determined by using following equation:

$$
I E \%=\left[\frac{W_{\text {corr }}-W_{\operatorname{corr}(i n h)}}{W_{\text {corr }}}\right] \times 100
$$

$$
\theta=\frac{W_{\text {corr }}-W_{\operatorname{corr}(i n h)}}{W_{\text {corr }}} \ldots \ldots \ldots
$$

where $W_{\text {corr(inh) }}$ and $W_{\text {corr }}$ are the weight loss values in the presence and in the absence of inhibitor, respectively.

$$
R_{\text {corr. }}=\frac{\Delta W * K}{A * D * t}
$$

Where $\Delta \mathrm{W}$ : weight losses of metal (gram), K: constant $\left(5.34 \times 10^{5}\right), \quad$ A: sample area $\left(\mathrm{cm}^{2}\right)$, D: metal density $\left(\mathrm{g} / \mathrm{cm}^{3}\right)$ and $\mathrm{t}$ : exposed time (hr).

Figure 1 shows the inhibition efficiencies (IE\%) obtained from the weight loss measurements of C-steel for different concentrations of azo compound in $1 \mathrm{M} \mathrm{HCl} 25^{\circ} \mathrm{C}$ with different times of immersion. The results of weight loss measurements reported in the Table 1. These results show that by increasing the time the efficiency increases as a result of increased $\theta$ and there is good inhibition process for this azo compound where the efficiency in the range 87.5$91.9 \%$ at the best time of $4 \mathrm{hr}$. There is clear effect of inhibitor concentration on the efficiency, as shown in Table 1. For the second medium $\mathrm{H}_{2} \mathrm{SO}_{4}$, inhibition efficiency is less for $\mathrm{HCl}$ medium (81.7$85.2 \%$ ) at time of $4 \mathrm{hr}$ but this efficiency still represent a good behavior of this azo dye on the corrosion protection of C-steel, as shown in Figure 2 and Table 2. 


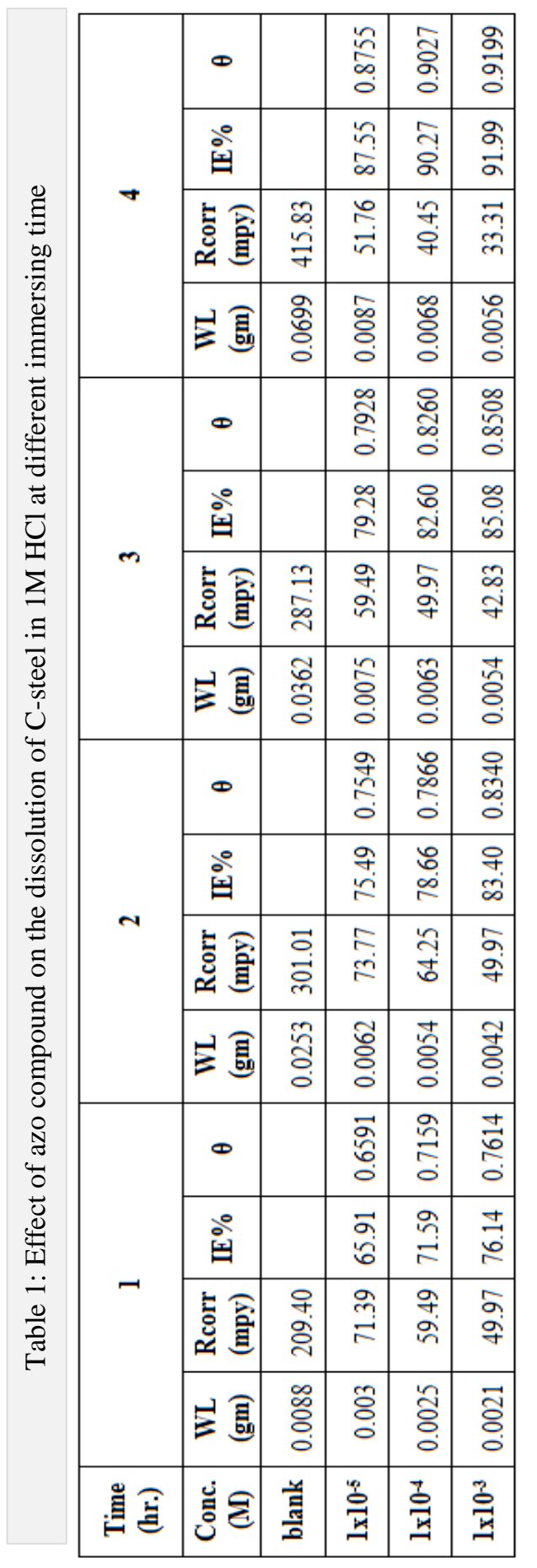

\begin{tabular}{|c|c|c|c|c|c|}
\hline \multirow{4}{*}{$\nabla$} & 0 & & 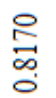 & 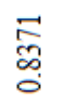 & $\begin{array}{l}\overrightarrow{\widehat{C}} \\
\text { O } \\
0\end{array}$ \\
\hline & 홉 & & 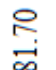 & $\overrightarrow{\mathrm{C}}$ & $\vec{\sim}$ \\
\hline & 产家 & 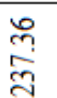 & $\begin{array}{l}\stackrel{⿰}{+} \\
\stackrel{y}{q}\end{array}$ & $\begin{array}{l}\hat{b} \\
\dot{m}\end{array}$ & 음 \\
\hline & 蒠 & જू & 厄. & 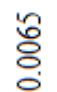 & 옹 \\
\hline \multirow{4}{*}{$m$} & 0 & & 总 & $\frac{\hbar}{2}$ & $\underset{\substack{\Delta \\
0}}{\overrightarrow{0}}$ \\
\hline & 울 & & 总 & హె & $\underset{\infty}{\exists}$ \\
\hline & 氮商 & $\begin{array}{l}\stackrel{8}{0} \\
\text { đેं }\end{array}$ & तె & $\begin{array}{l}8 \\
\text { i }\end{array}$ & 尔 \\
\hline & 蒠 & 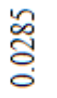 & 홍 & 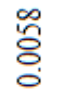 & 홍 \\
\hline \multirow{4}{*}{$\sim$} & 0 & & 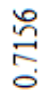 & 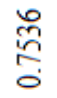 & $\frac{2}{2}$ \\
\hline & 돔 & & $\stackrel{\stackrel{\circ}{\gtrless}}{=}$ & 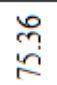 & $\frac{2}{2}$ \\
\hline & 氮啚 & 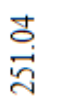 & 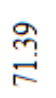 & $\stackrel{5}{\infty}$ & $\stackrel{n}{n}$ \\
\hline & 蒠 & 节 & ஓ & 命 & 蒿 \\
\hline \multirow{4}{*}{$=$} & 0 & & $\begin{array}{l}\text { O్ర్ర } \\
\text { : }\end{array}$ & 홍 & $\frac{\stackrel{0}{7}}{\stackrel{\overbrace{}}{0}}$ \\
\hline & 욷 & & $\begin{array}{l}\text { ઝે } \\
\text { త్ర }\end{array}$ & 룰 & 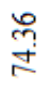 \\
\hline & 产家 & $\begin{array}{l}\vec{b} \\
\stackrel{\omega}{\sigma}\end{array}$ & $\begin{array}{l}\overrightarrow{0} \\
\text { هे }\end{array}$ & $\stackrel{m}{\stackrel{m}{n}}$ & 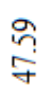 \\
\hline & 曷 & $\begin{array}{l}\infty \\
\stackrel{0}{\circ} \\
0\end{array}$ & ఫ్రి & ఫิ & ઠิ \\
\hline 罳兔 & ن & $\begin{array}{l}\text { 펼 } \\
\text { 영 }\end{array}$ & 突 & 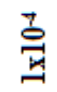 & 를 \\
\hline
\end{tabular}




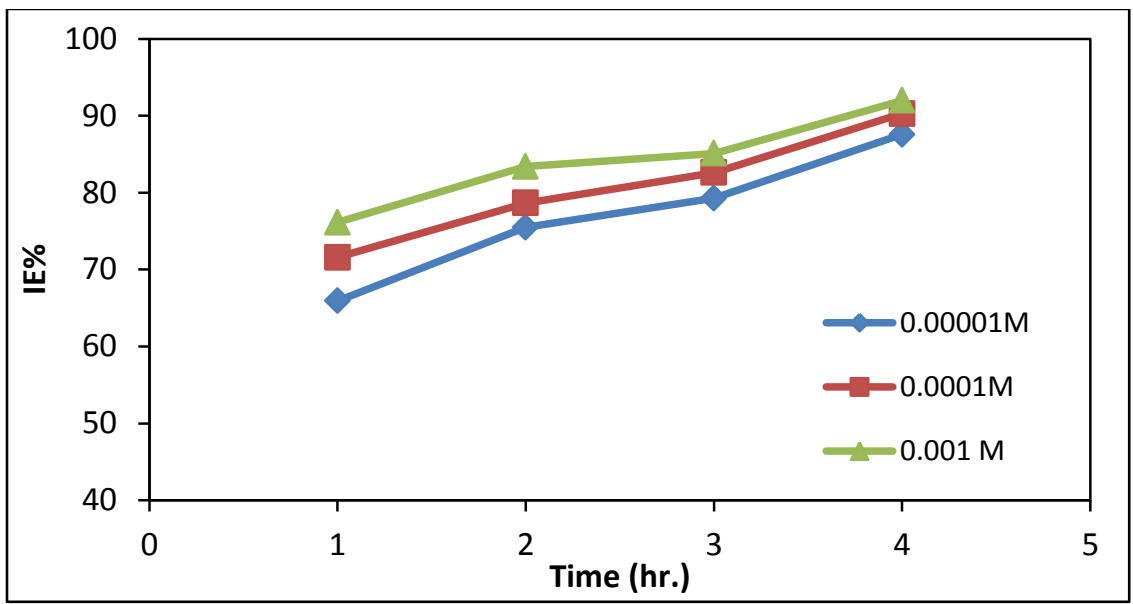

Figure 1: Inhibition efficiency IE\% in $\mathrm{HCl}$ with time in the presence of different concentrations of azo at $25^{\circ} \mathrm{C}$

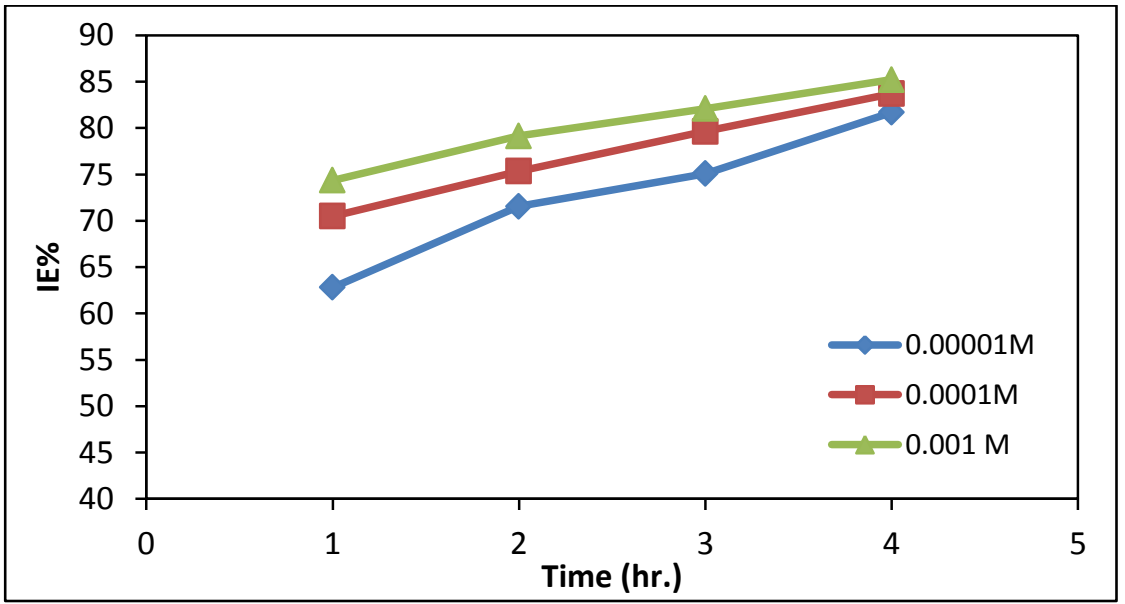

Figure 2: Inhibition efficiency IE\% in $1 \mathrm{M} \mathrm{H}_{2} \mathrm{SO}_{4}$ with time in the presence of different concentrations of azo at $25^{\circ} \mathrm{C}$

\subsubsection{Inhibition efficiency at different temperatures}

Figures 3 and 4 show the inhibition efficiencies (IE \%) obtained from the weight loss measurements of C-steel for different concentrations of azo compound in $1 \mathrm{M} \mathrm{HCl}$ and in $1 \mathrm{M} \mathrm{H}_{2} \mathrm{SO}_{4}$, respectively, at $4 \mathrm{hr}$ and at different temperatures. The results of weight loss measurements reported in the Tables 3 and 4 . These results show that there is reversed proportional relationship between efficiency and temperature. It is clear that the rate of corrosion increases as the temperature increases. This indicates that the rising of temperature decreases the inhibition efficiency and the best inhibition efficiency is obtained at $25^{\circ} \mathrm{C}$. 
Table 3: Effect of azo compound on the dissolution of $\mathrm{C}$-steel in $1 \mathrm{M} \mathrm{HCl}$ at different temperatures

\begin{tabular}{|c|c|c|c|c|c|c|c|c|c|c|c|c|}
\hline Temp. & \multicolumn{4}{|c|}{298} & \multicolumn{4}{|c|}{308} & \multicolumn{4}{|c|}{318} \\
\hline $\begin{array}{c}\text { Conc. } \\
\text { (M) }\end{array}$ & $\begin{array}{c}\text { WL } \\
(\mathbf{g m})\end{array}$ & $\begin{array}{l}\text { Rcorr } \\
\text { (mpy) }\end{array}$ & IE\% & $\boldsymbol{\theta}$ & $\begin{array}{c}\text { WL } \\
(\mathbf{g m})\end{array}$ & $\begin{array}{l}\text { Rcorr } \\
(\mathbf{m p y})\end{array}$ & IE\% & $\theta$ & $\begin{array}{c}\text { WL } \\
(\mathbf{g m})\end{array}$ & $\begin{array}{l}\text { Rcorr } \\
(\mathrm{mpy})\end{array}$ & IE\% & $\theta$ \\
\hline blank & 0.0699 & 415.82 & & & 0.0758 & 450.92 & & & 0.0969 & 576.44 & & \\
\hline $1 \times 10^{-5}$ & 0.0087 & 51.75 & 87.55 & 0.8755 & 0.0141 & 83.87 & 81.40 & 0.8140 & 0.0215 & 127.90 & 77.81 & 0.7781 \\
\hline $1 \times 10^{-4}$ & 0.0068 & 40.45 & 90.27 & 0.9027 & 0.0109 & 64.84 & 85.62 & 0.8562 & 0.0187 & 111.24 & 80.70 & 0.8070 \\
\hline $1 \times 10^{-3}$ & 0.0056 & 33.31 & 91.99 & 0.9199 & 0.0093 & 55.32 & 87.73 & 0.8773 & 0.0155 & 92.20 & 84.00 & 0.8400 \\
\hline
\end{tabular}

Table 4: Effect of azo compound on the dissolution of $\mathrm{C}$-steel in $1 \mathrm{M} \mathrm{H}_{2} \mathrm{SO}_{4}$ at different temperatures

\begin{tabular}{|c|c|c|c|c|c|c|c|c|c|c|c|c|}
\hline Temp. & \multicolumn{4}{|c|}{298} & \multicolumn{4}{|c|}{308} & \multicolumn{4}{|c|}{318} \\
\hline $\begin{array}{l}\text { Conc. } \\
\text { (M) }\end{array}$ & $\begin{array}{l}\text { WL } \\
(\mathrm{gm})\end{array}$ & $\begin{array}{l}\text { Rcorr } \\
(\mathbf{m p y})\end{array}$ & IE\% & $\boldsymbol{\theta}$ & $\begin{array}{c}\text { WL } \\
(\mathbf{g m})\end{array}$ & $\begin{array}{l}\text { Rcorr } \\
(\mathrm{mpy})\end{array}$ & IE\% & $\boldsymbol{\theta}$ & $\begin{array}{c}\text { WL } \\
(\mathrm{gm})\end{array}$ & $\begin{array}{l}\text { Rcorr } \\
(\mathrm{mpy})\end{array}$ & IE\% & $\boldsymbol{\theta}$ \\
\hline blank & 0.0399 & 237.36 & & & 0.0472 & 280.79 & & & 0.0693 & 412.26 & & \\
\hline $1 \times 10^{-5}$ & 0.0073 & 43.43 & 81.70 & 0.8170 & 0.0103 & 61.27 & 78.18 & 0.7818 & 0.0172 & 102.32 & 75.18 & 0.7518 \\
\hline $1 \times 10^{-4}$ & 0.0065 & 38.67 & 83.71 & 0.8371 & 0.0087 & 51.76 & 81.57 & 0.8157 & 0.0151 & 89.83 & 78.21 & 0.7821 \\
\hline $1 \times 10^{-3}$ & 0.0059 & 35.10 & 85.21 & 0.8521 & 0.0079 & 47.00 & 83.26 & 0.8326 & 0.0138 & 82.09 & 80.09 & 0.8009 \\
\hline
\end{tabular}

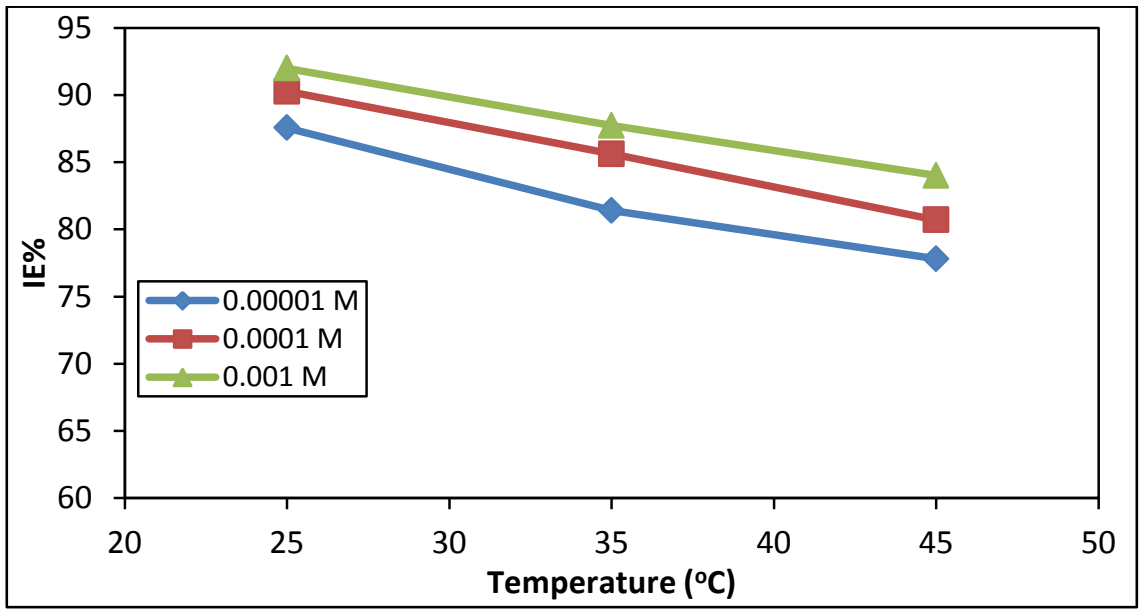

Figure 3: Inhibition efficiency $\mathrm{IE} \%$ in $\mathrm{HCl}$ as a function of the temperature in the presence of different concentrations of azo dye at $4 \mathrm{hrs}$ 


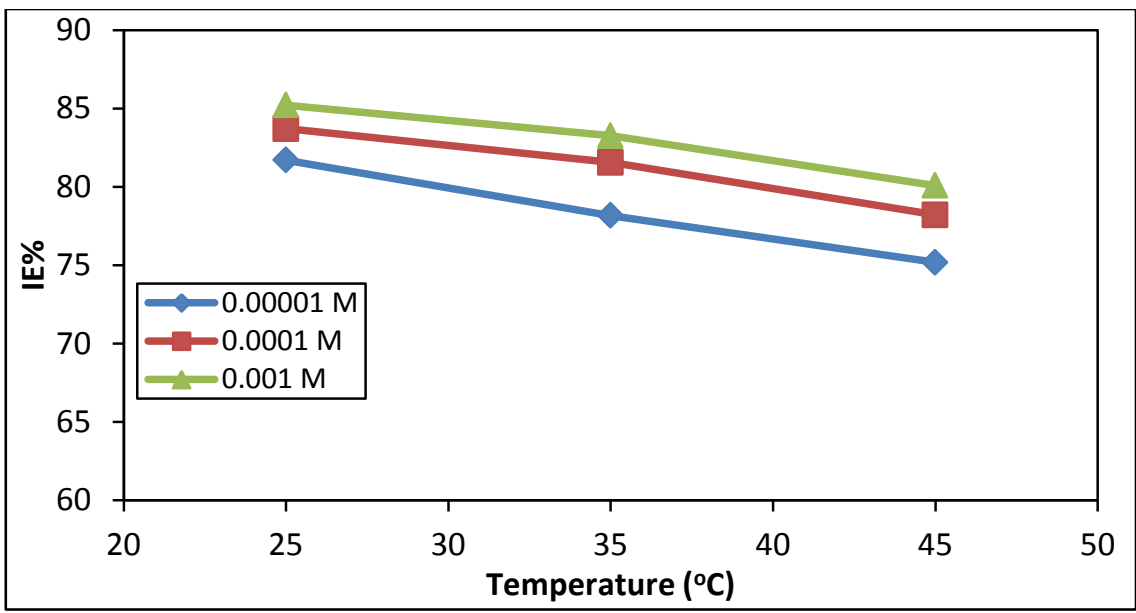

Figure 4: Inhibition Efficiency IE\% in $\mathrm{H}_{2} \mathrm{SO}_{4}$ as a function of the temperature in the presence of different concentrations of azo dye at $4 \mathrm{hrs}$

\subsection{Kinetic Parameters}

In order to obtain the effect of inhibitors on the kinetic parameters, gravimetric weight loss experiments were conducted at 25,35 and $45^{\circ} \mathrm{C}$ in $1 \mathrm{M} \mathrm{HCl}$ or $\mathrm{H}_{2} \mathrm{SO}_{4}$ after $4 \mathrm{hr}$ of immersion in the absence and presence of azo at $1 \times 10^{-3} \mathrm{M}$. The activation parameters for the system were calculated from Arrhenius-type plot (4) and transition state equation (5).

$$
\begin{aligned}
& \log \left(R_{\text {corr }}\right)=\frac{-E_{a c t}}{2.303 R T}+\log A-\ldots-\text { - (4) } \\
& R_{\text {corr }}=\frac{R T}{N h} \exp \left(\frac{\Delta S}{R}\right) \exp \left(-\frac{\Delta H}{R T}\right) \ldots \ldots
\end{aligned}
$$

Figures 5 and 6 show Arrhenius plot (log $\mathrm{R}_{\text {corr }}$ vs. $1 / \mathrm{T}$ ) for uninhibited carbon steel in $1 \mathrm{M}$ $\mathrm{HCl}$ and in $\mathrm{H}_{2} \mathrm{SO}_{4}$, respectively and in presence of the studied azo compound. The values of $E_{a}$ and Arrhenius factor can be obtained from the slope and the intercept of the straight lines, respectively and are given in Table 5. From the inspection of Table 5, it is clear that these values increase in the presence of the inhibitors. This was attributed to an appreciable decrease in the adsorption process of the inhibitor on the metal surface with increase of temperature and corresponding increase in the reaction rate because of the greater area of the metal that is exposed to acid solutions.

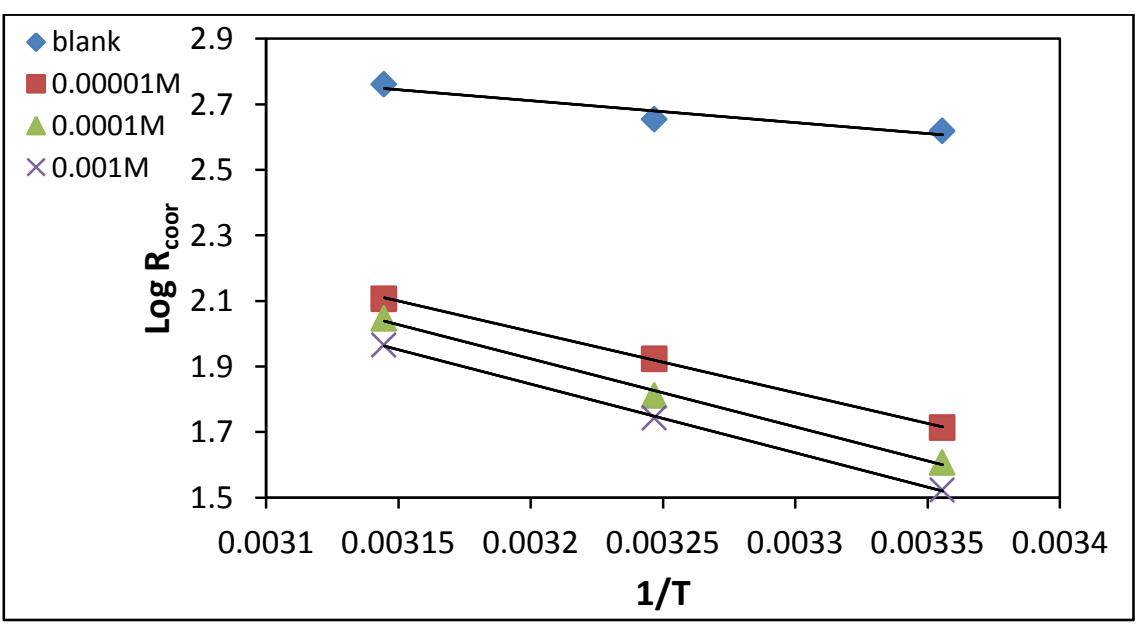

Figure 5: Arrhenius plots $\log \mathrm{R}_{\text {corr. }}$ versus $1 / \mathrm{T}$ at different concentration of azo dye in $\mathrm{HCl}$ 


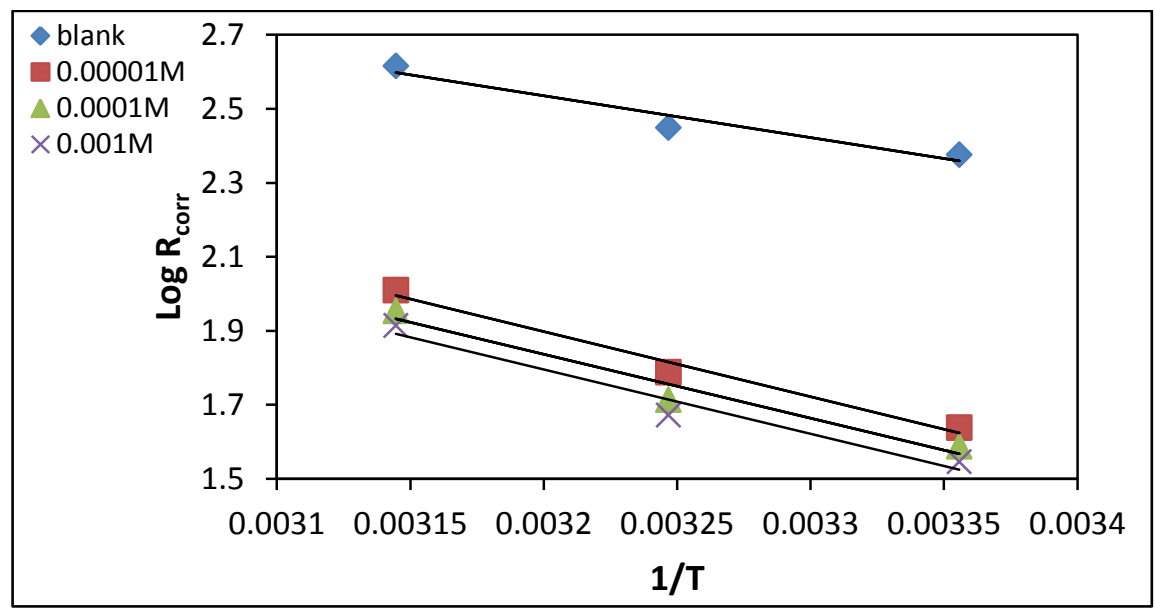

Figure 6: Arrhenius plots $\log \mathrm{R}_{\text {corr. }}$ versus $1 / \mathrm{T}$ at different concentration of azo dye in $\mathrm{H}_{2} \mathrm{SO}_{4}$

Table 5: Activation energy, Arrhenius factor, the enthalpy $\Delta \mathrm{H}$ of activation and the entropy of activation of azo inhibitor

\begin{tabular}{|c|c|c|c|c|c|c|c|c|}
\hline \multirow{3}{*}{$\begin{array}{c}\text { Conc. } \\
\text { (M) }\end{array}$} & \multicolumn{4}{|c|}{ in $\mathrm{HCl}$} & \multicolumn{4}{|c|}{ in $\mathrm{H}_{2} \mathrm{SO}_{4}$} \\
\hline & \multirow{2}{*}{$\begin{array}{c}\mathrm{A} \\
\times 10^{5}\end{array}$} & $\mathbf{E}_{\mathbf{a}}$ & $\Delta \mathbf{H}$ & $-\Delta S$ & \multirow{2}{*}{$\begin{array}{c}\text { A } \\
\times 10^{6}\end{array}$} & $\mathbf{E}_{\mathbf{a}}$ & $\Delta \mathbf{H}$ & $-\Delta S$ \\
\hline & & \multicolumn{3}{|c|}{$\left(\mathrm{kJmol}^{-1}\right)$} & & \multicolumn{3}{|c|}{$\left(\mathrm{kJmol}^{-1}\right)$} \\
\hline Blank & 0.705 & 12.72 & 10.23 & 0.161 & 1.42 & 21.63 & 19.09 & 0.136 \\
\hline $1 \times 10^{-5}$ & 923 & 35.68 & 33.09 & 0.101 & 33.7 & 33.67 & 31.11 & 0.109 \\
\hline $1 \times 10^{-4}$ & 3780 & 39.81 & 37.24 & 0.089 & 23.2 & 33.08 & 30.52 & 0.113 \\
\hline $1 \times 10^{-3}$ & 3520 & 40.02 & 37.53 & 0.090 & 23.4 & 33.35 & 30.79 & 0.112 \\
\hline
\end{tabular}

Figures 7 and 8 show a plot of $\log \left(\mathrm{R}_{\text {corr }} / \mathrm{T}\right)$ against (1/T). Straight lines are obtained with a slope of $(-\Delta \mathrm{H} / 2.303 \mathrm{R})$ and an intercept of (log $\mathrm{R} / \mathrm{Nh}+-\Delta \mathrm{S} / 2.303 \mathrm{R}$ ) from which the values of $\Delta \mathrm{H}$ and $\Delta \mathrm{S}$ are calculated and listed in Table 5. From inspection of Table 5 , it is clear that the positive values of $\Delta \mathrm{H}$ reflect that the process of adsorption of the inhibitors on the metal surface is an endothermic process. The values of $\Delta S$ in the presence and absence of the inhibitors are negative. This implies that the activation complex is the rate determining step representing association rather than dissociation, indicating that a decrease in disorder takes place on going from reactant to the activated complex [13]. 


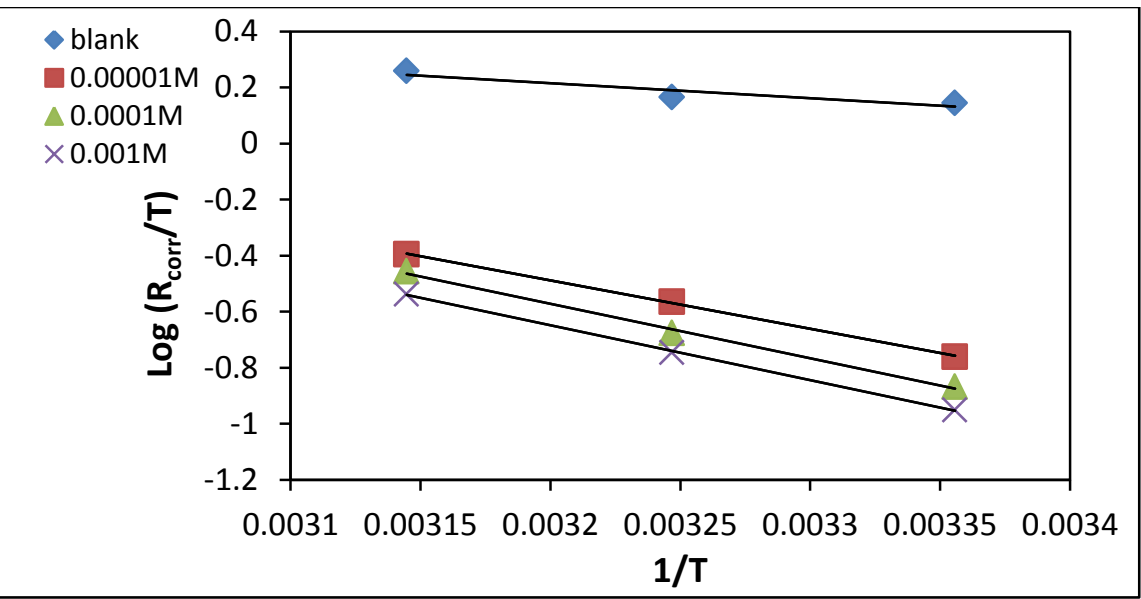

Figure 7: Arrhenius plots $\log \left(\mathrm{R}_{\text {corr }} / \mathrm{T}\right)$ versus $1 / \mathrm{T}$ at different concentrations of azo dye in $\mathrm{HCl}$

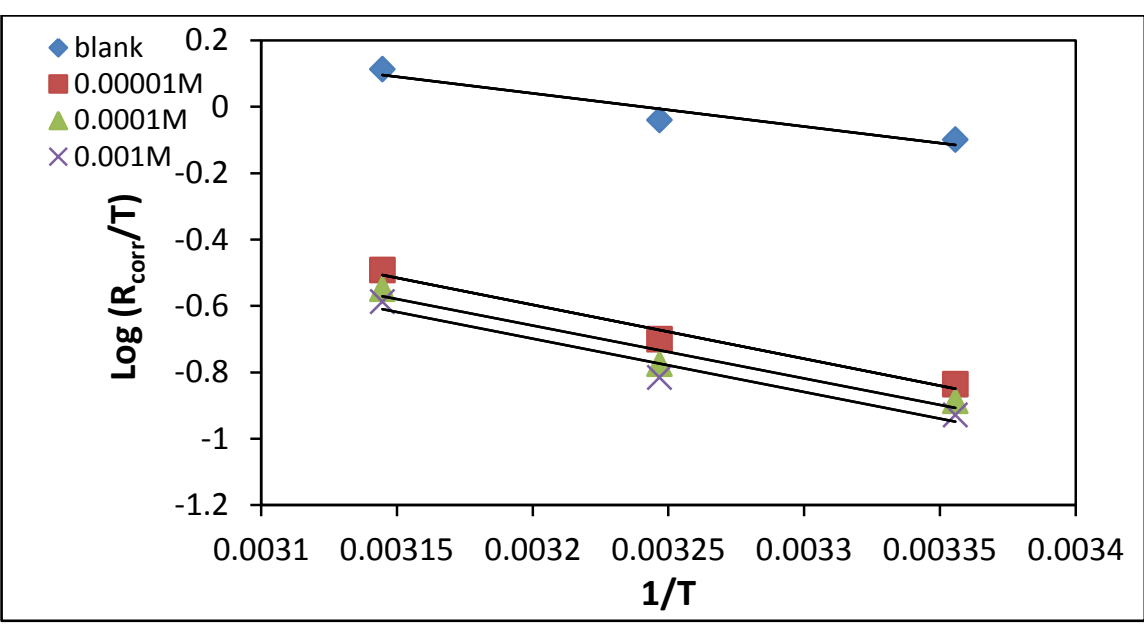

Figure 8 : Arrhenius plots $\log \left(\mathrm{R}_{\text {corr }} / \mathrm{T}\right)$ versus $1 / \mathrm{T}$ at different concentrations of azo dye in $\mathrm{H}_{2} \mathrm{SO}_{4}$

The relationship between the activation energy $\mathrm{Ea}$ and activation heat $\square \mathrm{H}$ against the concentration of azo is shown in Figures 9 and 10. From the data obtained in Table 5, it seems that Ea and $\square \mathrm{H}$ vary in the same manner. With an increase in concentration of azo dye, at first they increase, passing a maxima and thereafter remains approximately constant. This phenomenon is interpreted by the fact at a relative lower concentration around $10^{-5} \mathrm{M}$, the steel corrosion rate is chiefly decided by the kinetic parameters of activation[14]. 


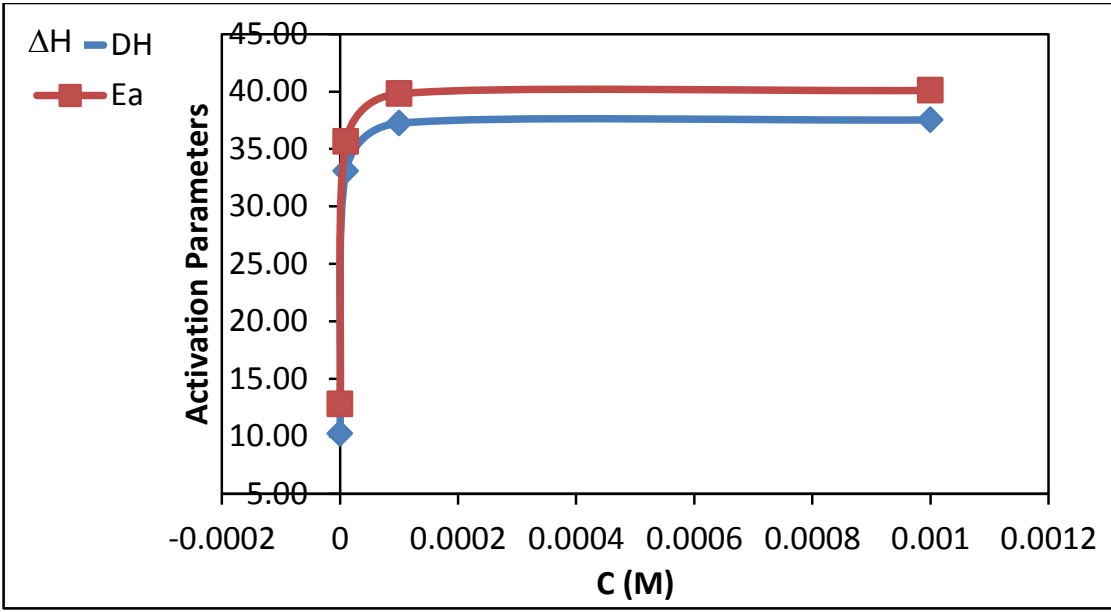

Figure 9: Variation of Ea and $\Delta \mathrm{H}$ versus concentration of azo dye in $\mathrm{HCl}$ solution

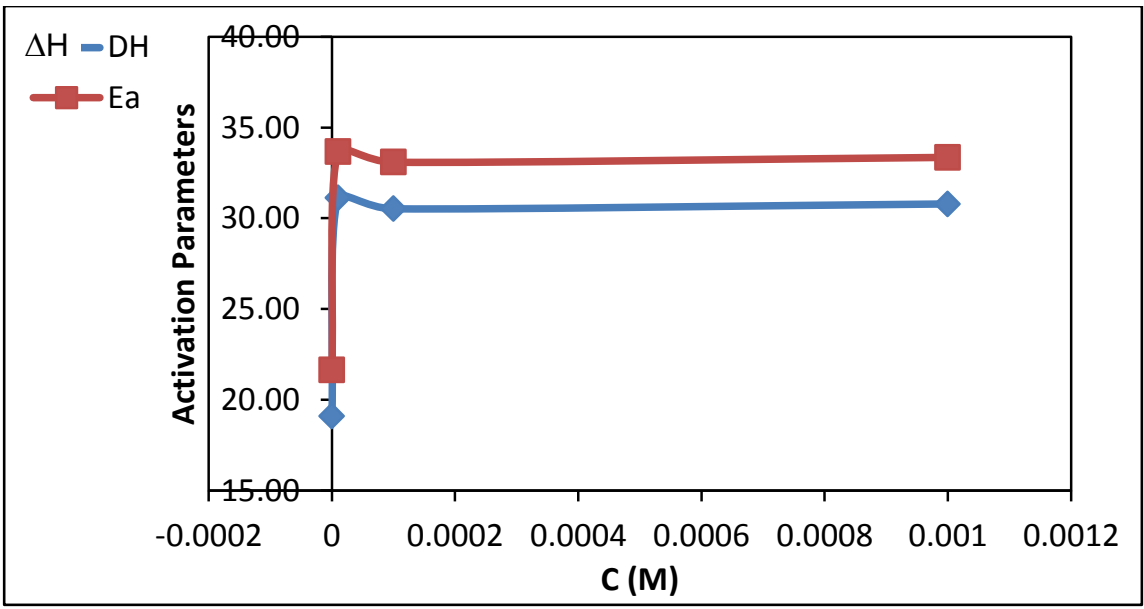

Figure 10: Variation of Ea and $\Delta \mathrm{H}$ versus concentration of azo dye in $\mathrm{H}_{2} \mathrm{SO}_{4}$ solution

\subsection{Adsorption Isotherm}

Adsorption isotherms are very important in understanding the mechanism of inhibition of corrosion reaction. The most frequently used adsorption isotherms are Frundlich, Langmuir, Frumkin, and Temkin isotherms. The best fitted one follows Langmuir isotherm. Plotting $(\mathrm{C} / \theta)$ versus concentration $(\mathrm{C})$ gives rise to straight lines, as shown in Figures 11 and 12. The obtained correlation coefficient $\mathrm{R}^{2}$ is higher than 0.99 indicating that the principle inhibition action following Langmuir isotherm model [15], as shown by the following equation:

$$
\frac{C}{\theta}=\frac{1}{K_{a d s}}+C
$$

The large values of $\mathrm{K}_{\mathrm{ads}}$ showed to strong adsorption process. The values of $\mathrm{K}_{\mathrm{ads}}$ can be calculated from the intercepts of the straight lines of Figures 11 and 12, which have large values which indicated to strong adsorption process. The standard free energy of adsorption, $\Delta \mathrm{G}_{\mathrm{ads}}$ in $\mathrm{kJ}$ $\mathrm{mol}^{-1}$ of the azo dye is related to $\mathrm{K}_{\mathrm{ads}}$ by the following equation:

$$
K_{a d s}=\frac{1}{55.5} \exp \left(\frac{-\Delta G_{a d s}^{o}}{R T}\right)-\cdots--(7)
$$


where 55.5 is the concentration of water in the solution in $\mathrm{mol} / \mathrm{L}, \mathrm{R}$ is the universal gas constant in $\mathrm{J} \mathrm{mol}^{-1} \mathrm{deg}^{-1}, \mathrm{~T}$ is the absolute temperature.

The values of $\Delta \mathrm{G}$ are found to be -41.28 , 43.88 and $-44.19 \mathrm{~kJ} \mathrm{~mol}^{-1}$ for $\mathrm{HCl}$ solution, and $43.57,-43.95$ and $-45.38 \mathrm{~kJ} \mathrm{~mol}^{-1}$ for $\mathrm{H}_{2} \mathrm{SO}_{4}$ solution. Generally, if the values of $\Delta \mathrm{G}$ lie in the range up to $-20 \mathrm{~kJ} / \mathrm{mol}$, they are consistent with physisorption, due to electrostatic interaction between the charged inhibiting species and the charged metal, while those above $-40 \mathrm{~kJ} / \mathrm{mol}$ are associated with chemisorption as a result of sharing or transfer of electrons from inhibiting species to the metal surface to form a metal bond. The calculated $\Delta \mathrm{G}_{\mathrm{ads}}$ values in this study, Table 6 , vary between $-41.28 \mathrm{~kJ} / \mathrm{mol}$ and $-45.38 \mathrm{~kJ} / \mathrm{mol}$. These values indicate that the adsorption mechanism of all concentrations of the used inhibitor on metal in $1 \mathrm{M} \mathrm{HCl}$ or $\mathrm{H}_{2} \mathrm{SO}_{4}$ solutions is through chemisorptions.

Table 6: Linear correlation coefficient $\mathrm{R}^{2}$, equilibrium constant $\mathrm{K}$ and the free energy of adsorption $\Delta \mathrm{G}_{\mathrm{ads}}$ of azo dye in different solutions

\begin{tabular}{|c|c|c|c|c|c|c|}
\hline \multirow{2}{*}{$\begin{array}{c}\text { Temp } \\
(\mathbf{K})\end{array}$} & $\begin{array}{c}|c| \\
\mathbf{K} \\
\left(\mathbf{m o l}^{-\mathbf{1}}\right)\end{array}$ & $\begin{array}{c}-\Delta \mathbf{G}_{\text {ads. }} \\
\mathbf{K J m o l}_{\mathbf{1}}^{-}\end{array}$ & $\mathbf{R}^{\mathbf{2}}$ & $\begin{array}{c}\mathbf{K} \\
\left(\mathbf{m o l}^{-\mathbf{1}}\right)\end{array}$ & $\begin{array}{c}-\Delta \mathbf{G}_{\text {ads. }} \\
\mathbf{K J m o l}_{\mathbf{1}}^{-}\end{array}$ & $\mathbf{R}^{\mathbf{2}}$ \\
\hline $\mathbf{3 9 8}$ & 50000 & 41.28 & 0.9969 & 78265.63 & 43.57 & 0.9913 \\
\hline $\mathbf{3 0 8}$ & 31034.7 & 43.88 & 0.9992 & 51429.75 & 43.95 & 0.9945 \\
\hline $\mathbf{3 1 8}$ & 32727.87 & 44.19 & 0.9959 & 50421.1 & 45.38 & 0.9958 \\
\hline
\end{tabular}

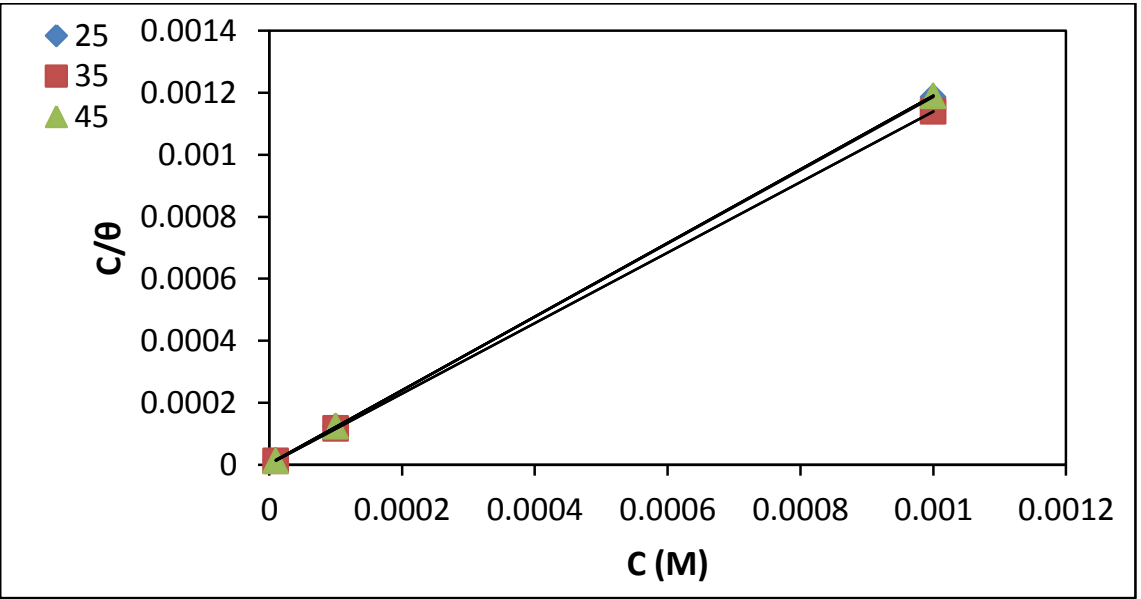

Figure 11: Langmuir adsorption isotherm of azo dye at different temperature in $\mathrm{HCl}$ solution 


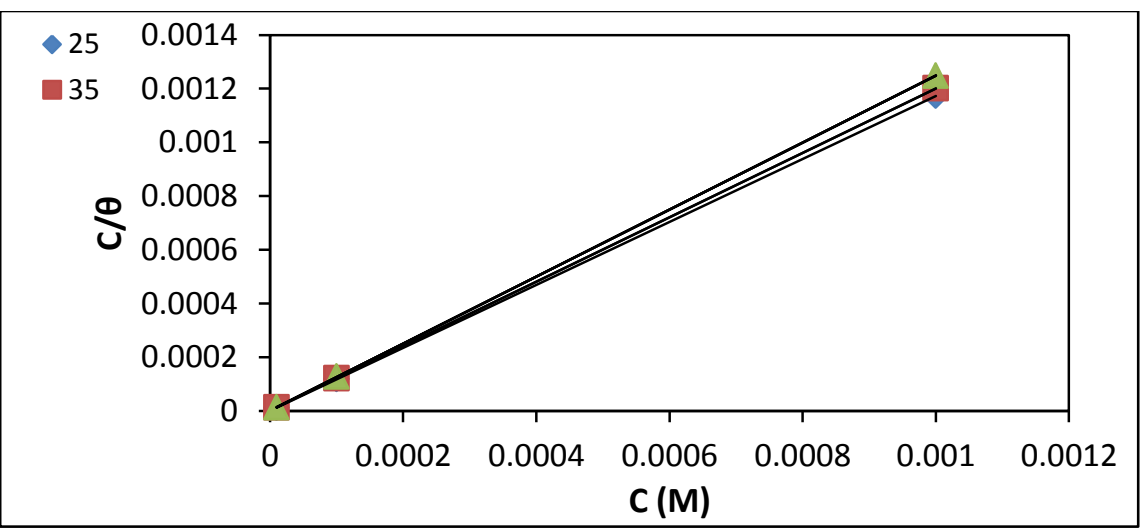

Figure 12: Langmuir adsorption isotherm of azo dye at different temperature in $\mathrm{H}_{2} \mathrm{SO}_{4}$ solution

\subsection{Potentiodynamic polarization measurements}

The inhibition efficiency was evaluated from the calculated $I_{\text {corr }}$ values using the relationship:

$$
E \%=\left[\frac{I_{\text {corr }}-I_{\text {corr }(\text { inh })}}{I_{\text {corr }}}\right] \times 100-\ldots-\ldots-\text { - - }(8)
$$

where $I_{\text {corr }}$ and $I_{\text {corr }(i n h)}$ are the corrosion current in the absence and in the presence of inhibitor, respectively.

The polarization curves of $\mathrm{C}$-steel in $1 \mathrm{M}$ $\mathrm{HCl}$ and $\mathrm{H}_{2} \mathrm{SO}_{4}$ with different concentrations of azo dye at $298 \mathrm{~K}$ are represented in Figures 13 and 14 , respectively. It is clear that the inhibition increases as the azo dye concentration increases. It is evident from the Tafel plots that the inhibitor adsorption shifted the corrosion potential $\left(\mathrm{E}_{\mathrm{corr}}\right)$ in the negative direction with reference to the blank in $1 \mathrm{M} \mathrm{HCl}$ or $\mathrm{H}_{2} \mathrm{SO}_{4}$, signifying that suppression of the cathodic reaction is the main effect of these corrosion inhibitors, Table 7.

Whereas, we found that by increasing the concentration, the current density decreases, which led to increase the corrosion efficiency. This may be attributed to decrease the adsorption process of inhibitor on the metal surface.

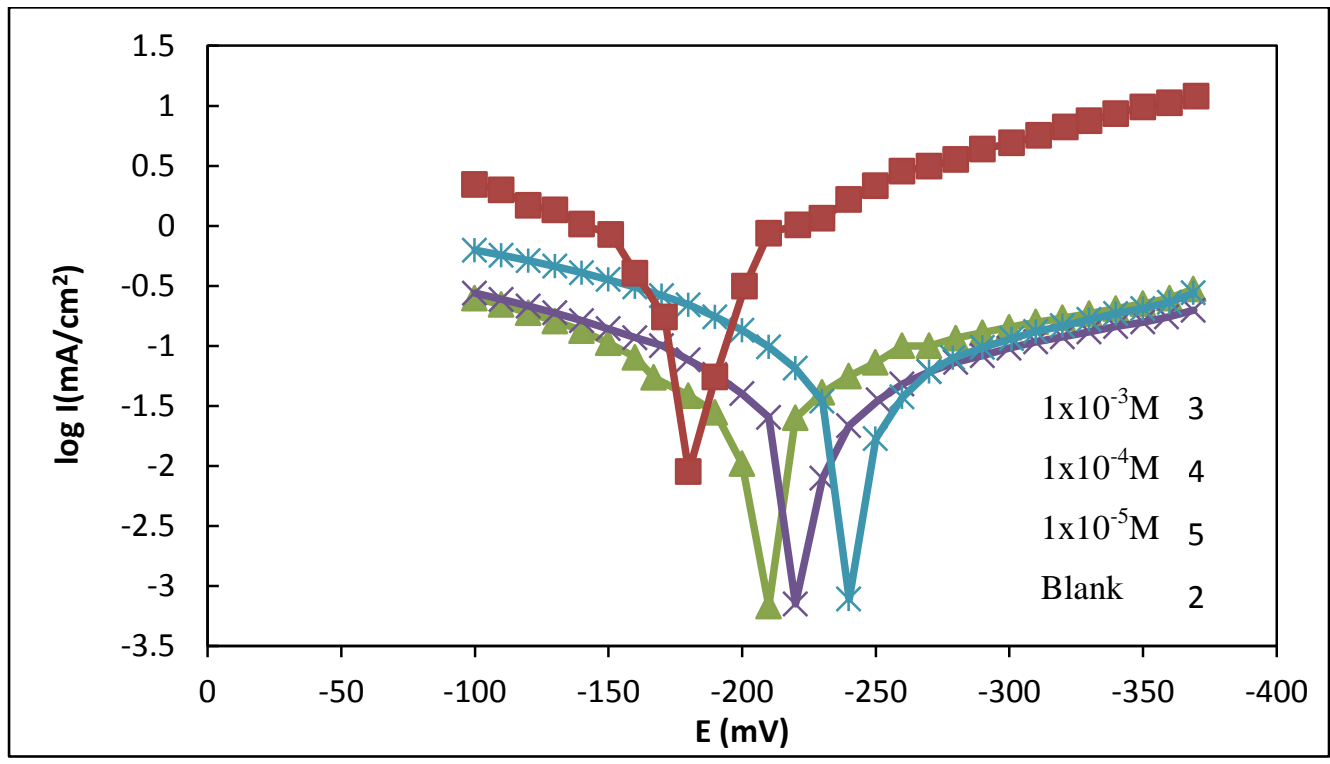

Figure 13: Anodic and cathodic polarization curves (Tafel curves) of mild steel in $1 \mathrm{M} \mathrm{HCl}$ and in the absence and presence of different concentration of inhibitor at $25^{\circ} \mathrm{C}$ 


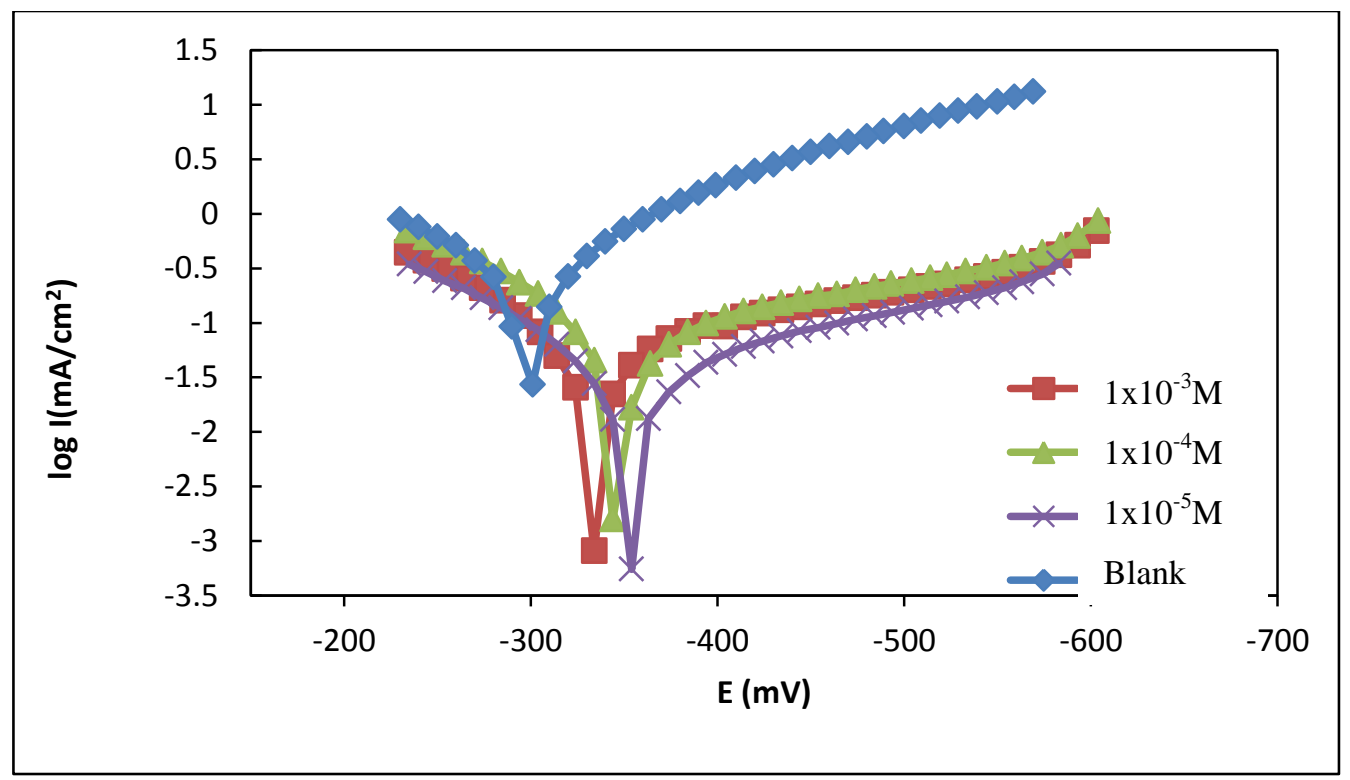

Figure 14: Anodic and cathodic polarization curves (Tafel curves) of mild steel in $1 \mathrm{M} \mathrm{HCl}$ and in the absence and presence of different concentration of inhibitor at $25^{\circ} \mathrm{C}$

Table 7: Electrochemical parameters for corrosion of mild steel in $1 \mathrm{M} \mathrm{HCl}$ and $\mathrm{H}_{2} \mathrm{SO}_{4}$ in the presence of different concentration of inhibitor

\begin{tabular}{|c|c|c|c|c|c|}
\hline $\begin{array}{c}\text { Inhibitor } \\
\text { Conc. } \\
\text { (M) }\end{array}$ & $\begin{array}{c}\text { Icorr. } \\
\mu \mathrm{A} / \mathrm{cm} 2\end{array}$ & $\begin{array}{l}\text { Ecorr. } \\
\text { mVolt }\end{array}$ & $\begin{array}{c}\mathrm{bC} \\
\mathrm{mV} / \mathrm{dm}\end{array}$ & $\begin{array}{c}\text { ba } \\
\mathbf{m V} / \mathbf{d m}\end{array}$ & $\mathrm{E} \%$ \\
\hline \multicolumn{6}{|c|}{ In $\mathbf{1 M} \mathrm{HCl}$} \\
\hline Blank & 460.3 & -185.3 & -113.1 & 95.2 & \\
\hline $1 \times 10^{-5}$ & 69.4 & -249.9 & -133.1 & 96 & 84.92 \\
\hline $1 \times 10^{-4}$ & 46.5 & -242.4 & -151.9 & 94 & 89.89 \\
\hline $1 \times 10^{-3}$ & 28.8 & -225.4 & -136.4 & 105.6 & 93.74 \\
\hline \multicolumn{6}{|c|}{ In $1 \mathrm{M} \mathrm{H}_{2} \mathrm{SO}_{4}$} \\
\hline Blank & 734.7 & -286.2 & -113.6 & 115.9 & \\
\hline $1 \times 10^{-5}$ & 137.4 & -349.3 & -174.5 & 88.8 & 81.29 \\
\hline $1 \times 10^{-4}$ & 117.2 & -343.4 & -185.7 & 94.2 & 84.04 \\
\hline $1 \times 10^{-3}$ & 97.4 & -358.8 & -128.8 & 99.6 & 86.74 \\
\hline
\end{tabular}

\subsection{Quantum Chemical Calculation}

In order to study the effect of molecular structure on the inhibition efficiency, quantum chemical calculations were performed to use semiempirical PM3 method. The optimized geometry of molecules is shown in Figure 8. The computed quantum chemical properties such as energy of highest occupied molecular orbital $\left(E_{\text {Номо }}\right)$, energy of lowest unoccupied molecular orbital $\left(E_{L U M O}\right)$, the energy band gap $(\Delta E)$ and dipole moment $(\mu)$ are summarized in the Table 5.

Table 5: Calculated quantum chemical parameters of the azo dve comnound

\begin{tabular}{|c|c|c|c|}
\hline$E_{\text {номо }}(\mathrm{eV})$ & $E_{\text {LUмо }}(\mathrm{eV})$ & $\boldsymbol{\Delta E}(\mathrm{eV})$ & $\boldsymbol{\mu}($ Debye $)$ \\
\hline-10.77 & -5.3347 & 5.4353 & 3.962 \\
\hline
\end{tabular}


$E_{\text {HOMO }}$ often indicates the electron donating ability of the molecule and the inhibition efficiency increases with the increasing $E_{\text {НОмо }}$ values. High $E_{\text {Номо }}$ values indicate that the molecule has a tendency to donate electrons to appropriate acceptor molecules with low energy empty molecular orbitals. The increasing values of the

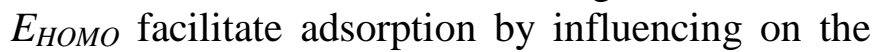
transport process through the adsorbed layer [16]. $E_{L U M O}$ indicates the ability of the molecules to accept electrons. The lower value of $E_{L U M O}$, the more probable the molecule accepts electrons. The energy gap between LUMO and HOMO $\left(\triangle E=E_{\text {LUMO }}-E_{\text {HOMO }}\right)$ is a parameter that the smaller value causes higher inhibition efficiencies of the

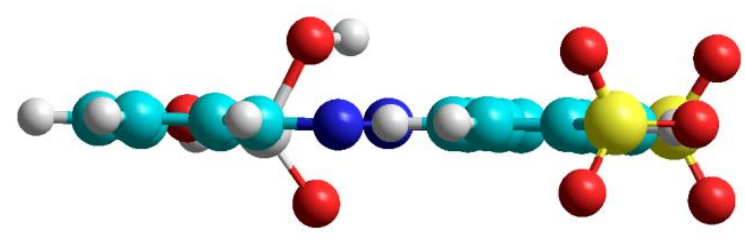

(a)

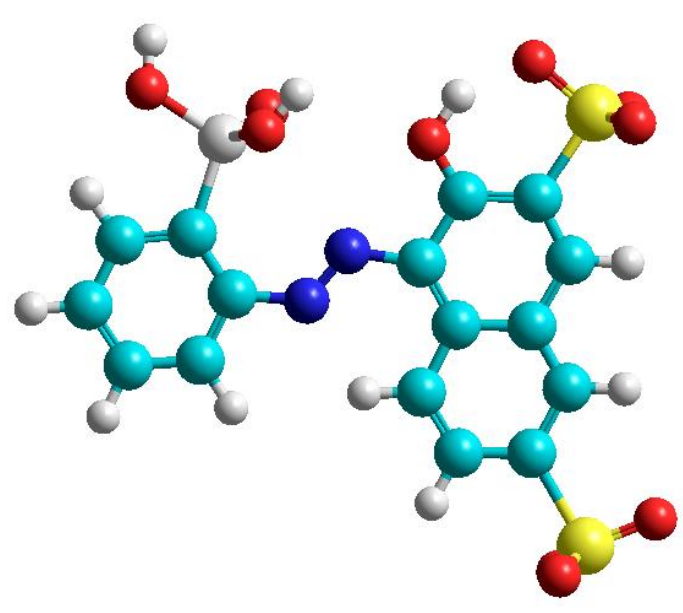

(b)

Figure 8: Optimized structures of thoron (a) is vertical view and (b) is plane view molecule,[17] as shown in Figure 9. For the dipole moment $(\mu)$, higher values will favorite enhancement of corrosion inhibition [18]. It is reported that excellent corrosion inhibitors are usually those organic compounds which not only offer electrons to the unoccupied $d$ orbital of the metal, but also accept free electrons from the metal into anti-bonding orbital to form a feedback bond [19].

It is clear from Table 5 that azo dye has the high values of $E_{\mathrm{HOMO}}, \mu$ and the low values of $E_{L U M O}$ and $\Delta \mathrm{E}$. These quantum chemical parameters indicate that this azo dye has high inhibition efficiency.

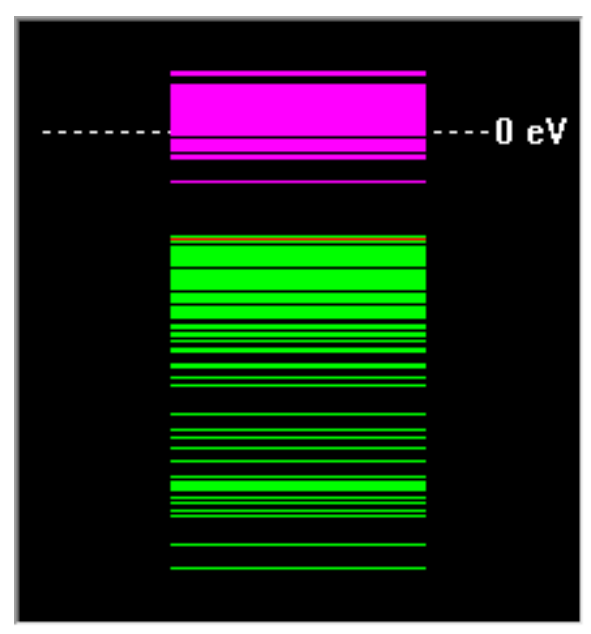

Figure 9: $E_{\text {Номо }}$ and $E_{L U M O}$ energy levels of thoron compound

\section{Conclusion}

The corrosion behavior of C-steel in $1 \mathrm{M} \mathrm{HCl}$ or $1 \mathrm{M} \mathrm{H}_{2} \mathrm{SO}_{4}$ solution in the absence and presence of thoron compound was investigated using weight loss and galvanostatic polarization techniques. From the results obtained the following conclusions could be drawn:

1- The thoron exhibited good surface properties and inhibition efficiency reaches to $93.7 \%$. The results show that its 
inhibition efficiencies in $1 \mathrm{M} \mathrm{HCl}$ and $1 \mathrm{M}$ $\mathrm{H}_{2} \mathrm{SO}_{4}$ solutions increased with increase its concentration, but decreased with increase temperature.

2- The adsorption of azo dye compounds on the carbon steel surface at different temperature was found to obey the Langmuir adsorption isotherm. The adsorption process is a spontaneous and high value of equilibrium constants.

3- There are good agreements between weight loss and galvanostatic polarization techniques to determine the efficiency of corrosion inhibitor.

4- The quantum chemical calculations show that energy of highest occupied molecular orbital $\left(E_{\text {НОмо }}\right)$, energy of lowest unoccupied molecular orbital $\left(E_{L U M O}\right)$, the energy band gap $(\Delta E)$ and dipole moment $(\mu)$ are found to correlate well with experimental inhibition efficiencies of inhibitors.

\section{References}

[1] G. Avci, Mater. Chem. Phys., 112, 234 (2008).

[2] E. Bayol, T. Gürten, A. A. Gürten, and M. Erbil, Mater. Chem. Phys., 112, 624 (2008).

[3] P. Lowmunkhong, D. Ungthararak and P. Sutthivaiyakit, Corr. Sci., 52, 30 (2010).

[4] H. H. Hassan, E. Abdelghani, and M. A. Amin,, Electrochim. Acta., 52, 6359 (2007).

[5] E. Ispir, Dye Pigment, $\underline{82}, 13$ (2009).

[6] H. Khanmohammadi and M. Darvishpour, J. Inorg. Organomet. Polym., 21, 541 (2011).

[7] H. Dinc aple, F. Toker, I. Durucasu, N. Avcibas, and I. S. Icli, Dye Pigment, 75, 11 (2007)

[8] S. Roy, T.N. Mandal, A.K. Barik, S. Pal, S. Gupta, A. Hazra, A.J. Butcher, A.D. Hunter,
M. Zeller and S.K. Kar, Polyhedron, 26, 2603 (2007)

[9] M. Odabas,og lu, C, . Albayrak, R. O“zkanca, F.Z. Aykan and P. Lonecke, J. Mol. Struct., 71, 840, (2007)

[10] D. Zhang, M. Zhang, Z. Liu, M. Yu, F. Li, T. Yi and C. Huang, Tetrahedron Lett., 47, 7093 (2006)

[11] P. Pattanyak, J.L. Pratihar, D. Patra, V.G. Puranik and S. Chatto-padhyay, Polyhedron, 27, 2209 (2008)

[12] A. M. Ali, H. J. Mohammed and A. J. Khadhim, Islamic University J., ㅁ, 85(2008).

[13] Salih S. Al-Juaid, Portugaliae Electrochimica Acta, 25, 363 (2007).

[14] M. Bouklah, B. Hammouti, M. Lagrene and F.

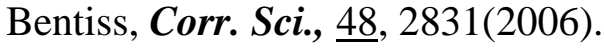

[15] E.E. Abd El Aal, S. Abd El Wanees, A. Farouk and S.M. Abd El Haleem, Corr. Sci., $\underline{68}, 14(2013)$.

[16] M. Behpour, S. M. Ghoreishi, N. Soltani, M. Salavati-Niasari, M. Hamadanian and A. Gandomi, Corr. Sci., 50, 2172(2008).

[17] Y. M. Tang, W. Z. Yang, X. S. Yin, Y. Liu, R. Wan and J. T. Wang, Materials Chemistry and Physics, 116, 479(2009).

[18] M. Lebrini, M. Lagrenee, M. Traisnel, L. Gengembre, H. Vezin and F. Bentiss, Appl. Sur. Sci., Vol. 253, No. 23, 2007, 9267

[19] P. Zhao, Q. Liang and Y. Li, Appl. Sur. Sci., 252, 1596( 2005). 